\title{
Analgesic and Antidiarrheal Activities of Leaf of Podocarpus neriifolius D. Don
}

\section{Md. Rahatullah Razan', Muhammed Mahfuzur Rahman², Faiza Tahia, Md. Khalid Hossain $^{1}$ and Mohammad A. Rashid ${ }^{1}$}

${ }^{1}$ Phytochemical Research Laboratory, Department of Pharmaceutical Chemistry, Faculty of Pharmacy, University of Dhaka, Dhaka-1000, Bangladesh

${ }^{2}$ Department of Pharmacy, State University of Bangladesh, Dhaka-1205, Bangladesh

Received: June 28, 2016; Accepted: July 24, 2016; Published (Web): July 31, 2016

\begin{abstract}
The methanol extract of leaf of Podocarpus neriifolius D. Don exhibited in vivo peripheral analgesic and antidiarrheal activities in Swiss Albino mice. In the peripheral analgesic activity assay, the methanolic extract showed $50.00 \pm 8.57 \%$ and $70.25 \pm 1.18 \%$ inhibition of acetic acid-induced writhing at 200 and $400 \mathrm{mg} / \mathrm{kg}$ body weight, respectively. In addition, the extract also revealed a dose dependant inhibition of castor oilinduced diarrhea with $43.77 \pm 3.13 \%$ and $56.23 \pm 6.49 \%$ inhibition of feces at 200 and $400 \mathrm{mg} / \mathrm{kg}$ body weight, respectively.
\end{abstract}

Key words: Analgesic activity, castor oil, diarrhea

\section{Introduction}

Podocarpus neriifolius D. Don, also known as brown pine, is a species belonging to the Podocarpaceae family. It grows $10-15 \mathrm{~m}$ tall, though very occasionally taller, in tropical and sub-tropical wet closed forests, between $650 \mathrm{~m}$ and $1600 \mathrm{~m}$ altitudes. Traditionally, it is used to treat joint pain due to rheumatism and arthritis (Abdillahi et al., 2010). Other plants of the Podocarpus genus have been reported to be febrifuge, anti-inflammatory and expectorant (Abdillahi et al., 2011). Majority of the people in the developing countries use different types of this herbal concoction in diarrhea and pain. Diarrhea is also considered one of the leading causes of mortality in the developing countries. As part of our ongoing research with medicinal plants of Bangladesh (Tahia et al., 2015, Aktar et al., 2015), the present work has been undertaken to evaluate the analgesic and antidiarrheal potential of a crude methanol extract of the leaves of $P$. neriifolius and we, here in, report the results of our preliminary investigations.

Correspondence to: Md. Khalid Hossain; E-mail: hossainkhalid2004@ yahoo.com

\section{Materials and Methods}

Collection and preparation of plant materials: Fresh leaves of $P$. neriifolius were collected from the hill tracts of Chittagong, Bangladesh in September 2013. It was then identified by the taxonomist of Bangladesh National Herbarium, where a voucher specimen (DACB - 39344) has been maintained. The clean leaves were sun dried and ground to a coarse powder. Then $500 \mathrm{gm}$ of this powder was soaked in 3 liters of methanol in a flat bottom flask. The container was sealed with a cotton plug and kept for 7 days with occasional shaking to facilitate the extraction of phytoconstituents. The whole mixture was filtered by cotton plug followed by Whatman number 1 filter paper and the filtrate was evaporated to dryness with a rotary evaporator at reduced temperature and pressure. The concentrated gummy mass was transferred to a clean beaker and stored in refrigerator until used for further experiments.

Drugs and chemicals: Acetic acid, methanol and Tween-80, loperamide (Square Pharmaceutical Ltd., Bagladesh), and diclofenac sodium and normal saline 
(Incepta Pharmaceutical Ltd., Bangladesh) were used. Highly purified castor oil was purchased from local market. All other reagents were of analytical grade.

Experimental animals: Swiss Albino mice of both sexes weighing between 25-35 gm and 4-5 weeks old were obtained from the Department of Pharmacy, Jahangirnagar University. The mice were kept in the animal house of the State University of Bangladesh and fed with standard rodent feed. As these animals are sensitive towards environmental change, they were kept for 4 days in the laboratory environment prior to use for the experiments. The Federation of European Laboratory Animal Science Associations (FELASA) guidelines and recommendations were followed to reduce the pain and stress of the experimental mice.

Grouping of mice: Twenty four Swiss Albino mice were randomly divided into four groups of six animals in each group for each bioassay: positive control, negative control and two test groups receiving methanolic extract at doses of 200-(PN1) and 400$\mathrm{mg} / \mathrm{kg}$ of body weight (PN2). Peripheral analgesic activity: Analgesic activity was evaluated by acetic acid-induced writhing method as described by Koster $e t$ al. (1959). In this method, $0.1 \mathrm{ml}$ of acetic acid was administered intraperitoneally to the experimental animals to create pain sensation, where, the animals started to squirm their body at regular interval due to pain. This squirm or contraction of the body is termed as "writhing". As long as the animals feel pain, they continue to give writhing. Each writhing is counted and taken as an indication of pain sensation. Any substance that exhibits analgesic activity is supposed to lessen the number of writhing in animals within a given time frame with respect to the control group. As positive control, each mouse received $5 \mathrm{mg} / \mathrm{kg}$ body weight of diclofenac sodium through intraperitoneal route. In the experimental group the crude extract was used for the evaluation of analgesic activity at 200 -and $400-\mathrm{mg} / \mathrm{kg}$ of body weight and the percentage of writhing inhibition was calculated by using the following equation:

Inhibition $(\%)=[(\mathrm{Wc}-\mathrm{Wt}) \times 100] / \mathrm{Wc}$

Where, Wt is the average number of writhing reflex in the test group and $\mathrm{Wc}$ is the average number of writhing reflex in the negative control group.
Antidiarrheal activity: The antidiarrhoeal activity of the methanolic extract of leaves of $P$. neriifolius was evaluated by using castor oil-induced diarrhea in mice, the experimental details of which could be found elsewhere (Shaoba and Thomas, 2001). Here, the animals were divided into negative control, positive control and test groups. Each mouse was fed with 1.0 $\mathrm{ml}$ of highly pure analytical grade castor oil. Negative control group received vehicle (1\% Tween-80 in water), while the positive control group was administered with loperamide at $50 \mathrm{mg} / \mathrm{kg}$ body weight orally. The test groups received methanol extract at 200 and $400 \mathrm{mg} / \mathrm{kg}$ body weight orally. The number of fecal stools was recorded for the individual mouse. The results of the experimental groups were compared with that of the control groups to evaluate the antidiarrheal activity. The percentage inhibition of defecation in mice was calculated by using the following equation:

$\%$ inhibition $=[(\mathrm{Mo}-\mathrm{M}) / \mathrm{Mo}] \times 100 ;$ where, Mo $=$ Mean defecation of negative control and $\mathrm{M}=$ Mean defecation of test sample or standard (positive control).

Statistical analysis: The values are presented as mean \pm standard error of mean (SEM) and One way ANOVA followed by Dunnett's test were used to determine the significance difference between the control group and experimental groups, the $\mathrm{p}$ values < 0.05 were considered to be statistically significant.

\section{Results and Discussion}

The effects of methanolic extract of the leaves of $P$. neriifolius in acetic acid-induced writhing are shown in table 1. The number of contraction of abdominal muscle induced by $0.1 \mathrm{ml}$ of acetic acid was effectively reduced by the extract in a dose dependant manner. Statistical evaluation of the data confirmed that the crude methanolic extract of leaves of $P$. neriifolius demonstrated significant peripheral analgesic activity having writhing inhibition of $50 \pm 8.57 \%$ and $70.25 \pm$ $1.18 \%$ at $200-$ and $400-\mathrm{mg} / \mathrm{kg}$ of body weight, respectively when compared to that of the standard diclofenac sodium $(77.39 \pm 0.68 \%$ inhibition). 
The antidiarrheal activity of the methanolic extract of the leaves of $P$. neriifolius is shown in table 2. The extract reduced the castor oil induced diarrheal feces by
$43.77 \pm 3.13 \%$ and $56.23 \pm 6.49 \% \quad(\mathrm{p}<0.05)$ at the dose of 200 -and $400-\mathrm{mg} / \mathrm{kg}$ of body weig, respectively.

Table 1. Peripheral analgesic activity of crude methanol extract of $P$. neriifolius leaves.

\begin{tabular}{lccccc}
\hline Animal group & \multicolumn{3}{c}{ Writhing count } & $\begin{array}{c}\text { Number of writhing } \\
\text { (Mean } \pm \text { SEM) }\end{array}$ & $\begin{array}{c}\text { \% Inhibition of writhing } \\
\text { (Mean } \pm \text { SEM) }\end{array}$ \\
\cline { 2 - 4 } & M-1 & M-2 & M-3 & $28 \pm 1.15$ & - \\
NC & 28 & 30 & 26 & $6.33 \pm 0.33$ & $77.39 \pm 0.68^{* *}$ \\
PC & 6 & 6 & 7 & $14 \pm 4.16$ & $50 \pm 8.57^{*}$ \\
PN 1 & 12 & 22 & 8 & $8.33 \pm 0.88$ & $70.25 \pm 1.18^{* *}$ \\
PN 2 & 10 & 7 & 8 & & \\
\hline
\end{tabular}

Values are expressed as Mean \pm SEM $(n=3) . * * p<0.01,{ }^{*} p<0.05$ compared to negative control. NC $=$ negative control $(1 \%$ Tween 80 in water), $\mathrm{PC}=$ positive control (Diclofenac sodium at $5 \mathrm{mg} / \mathrm{kg}$ body weight), PN1 = Methanolic extract of $P$. neriifolius leaves at $200 \mathrm{mg} / \mathrm{kg}$ body weight, PN2 = Methanolic extract of $P$. neriifolius leaves at $400 \mathrm{mg} / \mathrm{kg}$ body weight. M1, M2, M3 = Mice 1, Mice 2, Mice 3, respectively.

Table 2. Effect of methanol extract of $P$. neriifolius leaves on castor oil-induced diarrhea in mice.

\begin{tabular}{lccc}
\hline Treatment & Dose & $\begin{array}{c}\text { Number of diarrheal feces } \\
(\text { Mean } \pm \text { SEM) }\end{array}$ & $\begin{array}{c}\text { \% Reduction of diarrhea } \\
(\text { Mean } \pm \text { SEM) }\end{array}$ \\
\hline Negative control (Saline) & $10 \mathrm{ml} / \mathrm{kg} \mathrm{b.w.}$ & $10.67 \pm 1.33$ & - \\
Positive control (Loperamide) & $50 \mathrm{mg} / \mathrm{kg} \mathrm{b.w.}$ & $2.33 \pm 0.33$ & $78.16 \pm 1.78^{* *}$ \\
PN1 & $200 \mathrm{mg} / \mathrm{kg} \mathrm{b.w.}$ & $6.00 \pm 0.58$ & $43.77 \pm 3.13^{*}$ \\
PN2 & $400 \mathrm{mg} / \mathrm{kg}$ b.w. & $4.67 \pm 1.20$ & $56.23 \pm 6.49^{*}$ \\
\hline
\end{tabular}

Values are expressed as Mean \pm SEM $(n=3)$. $* * p<0.01, * p<0.05$ compared to control (One way ANOVA followed by Dunnett's test). Positive control $=($ Loperamide at $50 \mathrm{mg} / \mathrm{kg}$ body weight $), \mathrm{PN} 1$ and PN2 = Methanolic extract of $P$. neriifolius leaves at 200 $\mathrm{mg} / \mathrm{kg}$ body weight and $400 \mathrm{mg} / \mathrm{kg}$ body weight, respectively.

The dose depended reduction of diarrheal feces by the methanolic extract of $P$. neriifolius leaves was found to be significant when compared to the reduction of diarrheal feces by loperamide. Ricinolic acid which is the active metabolite of castor oil stimulates peristaltic activity in the small intestine, leading to changes in electrolyte permeability of the intestinal mucosa (Ammon et al., 1974; Tanko et al., 2012). The liberated ricinoleic acid also causes irritation and inflammation of the intestinal mucosa leading to the release of endogenous prostaglandins. Other mechanisms of castor oil induced diarrhea include inhibition of intestinal $\mathrm{Na}+\mathrm{K}+$ - ATPase activity, activation of adenylate cyclase or mucosal cAMP mediated active secretion and platelet activating factor (Meite et al., 2009). The decrease in the wetness of feces and the frequency of defecation as well as the decrease in the intensity and frequency of body squirming observed, proved the potent antidiarrhoeal and analgesic activities of $P$. neriifolius leaves which might be due to the inhibition of prostaglandins biosynthesis. Previous phytochemical screenings of the plant extract revealed the presence of terpenoids, steroids, flavanoids, polyphenolics and fats (Zhen et al., 1993; Rashid et al., 2014). Many plants exhibited analgesic and antidiarrheal activities due to the presence of saponins, terpenoids, steroids and flavonoids (Owleye et al., 2005). It is not unreasonable, therefore to speculate that the terpenoids, steroids and flavonoids present in the plant extract may be responsible for the observed analgesic and antidiarrheal activities. 


\section{Conclusion}

The results of our preliminary studies indicated potent analgesic and antidiarrheal activities of $P$. neriifolius leaves. Thus, the plant warrants further investigation to isolate the active constituents responsible for these activities and to establish the mechanism(s) of action.

\section{References}

Abdillahi, H.S., Finnie, J.F. and Van Staden, J. 2011. Antiinflammatory, antioxidant, anti-tyrosinase and phenolic contents of four Podocarpus species used in traditional medicine in South Africa. J. Ethnopharmacol. 136, 496503.

Abdillahi, H.S., Stafford, G.I., Finnie, J.F. and Van Staden, J. 2010. Ethnobotany, phytochemistry and pharmacology of Podocarpus sensu latissimo (s.1.). South African J. Bot. 76, 1-24.

Aktar, S., Bilkiss, M., Tahia, F., Majumder, P., Sikder, M.A.A. and Rashid, M.A. 2015. Bioactivities of Chukrasia tabularis (A. Juss.). Bangladesh Pharm. J. 18, 126-131.

Ammon, H.V., Thomas, P.L. and Phillips, S.F. 1974. Effects of oleic and ricinoleic acids on net jejunal water and electrolyte movement: perfusion studies in man. J. Clin. Invest. 53, 374-379.

Koster, R., Anderson, M. and De Beer, E.J. 1959. Acetic acid for analgesic screening. Proc. Soc. Exp. Biol. Med. 18, 412-415.
Meite, S., N'guessan, J.D., Bahi, C., Yapi, H.F., Djaman, A.J. and Guina, F.G. 2009. Anti-diarrheal activity of the ethyl acetate extract of Morinda morindoides in rats. Trop. J. Pharm. Res. 8, 201-207.

Oweyele, V.B., Oloriegbe, Y.Y., Balogun, E.A. and Soladoye, A.O. 2005. Analgesic and anti-inflammatory properties of Nelsonia canescens leaf extract. $J$. Ethnopharmacol. 99, 153-56.

Rashid, M.A., Haque, M.R., Sikder, M.A.A., Chowdhury, A.A., Rahman, M.S., and Hasan, C.M., 2014. Review of bioactivities of secondary metabolites from some medicinal plants and microbes of Bangladesh. Bangladesh Pharm. J. 17, 63-79.

Shoba, F.G. and Thomas, M. 2001. Study of anti-diarrheal activity of four medicinal plants in castor oil induced diarrhea. J. Ethnopharmacol. 76, 73-76.

Tahia, F., Sikder, M.A.A., Rashid, R.B. and Rashid, M.A. 2015. Studies of Bioactivities of Adansonia digitata (L.). Dhaka Univ. J. Pharm. Sci. 14, 157-162.

Tanko, Y., Alladey, O., Ahmed, M.K., Mohammed, A. and Musa, K.Y. 2012. The effect of methanol leaves extract of Ficus glumosa on gastrointestinal motility and on castor oil induced diarrhea in laboratory animals. J. Nat. Prod. Plant. Resour. 2, 360-367.

Zhen, X.L., Zhen, C. and Nan-jun, S. 1993. Studies on chemical compositions of Podocarpus neriifolius D. Don. Acta Botanica sinica 35, 138-143 